\section{New genus-specific primers for the PCR identification of members of the genus Saccharomonospora and evaluation of the microbial diversity of wild-type isolates of Saccharomonospora detected from soil DNAs}

\author{
Oscar Salazar, Raquel Morón and Olga Genilloud
}

Centro de Investigación Básica, Natural Products Drug Discovery, Merck Research Laboratories, Merck Sharp and Dohme de España SA, Josefa Varcárcel 38, E-28027 Madrid, Spain Author for correspondence: Olga Genilloud. Tel: +34 913210 568. Fax: + 34913210614.
e-mail: olga_genilloud@merck.com
Keywords: Saccharomonospora, PCR primers, 16S rDNA sequences, ribosomal internal transcribed spacers (ITSs), soil DNA

\section{INTRODUCTION}

Historically, natural products screening programmes have focused on the order Actinomycetales, one of the most intensively isolated groups of micro-organisms, which has efficiently demonstrated its ability to produce a large diversity of new secondary metabolites

\footnotetext{
Abbreviations: ITS, internal transcribed spacer; $T_{m}$, melting temperature; UPGMA, unweighted pair group method with arithmetic averages.

The EMBL accession numbers for the partial 16S rRNA gene sequences of Saccharomonospora sp. isolates 12-82, 02-103, 42-146, 42-147, 42-157, $42-161 ， 42-162,42-17,42-182,42-187,42-190,42-193,42-27,42-78$ 42-82 and 42-86 are AJ270373-AJ270388, respectively. The EMBL accession numbers for the 16S-23S rDNA internal transcribed spacers of Saccharomonospora sp. isolates 42-147, 42-15, 42-157, 42-161, 42-162, 42-166, 42-168, 42-169, 42-17, 42-175, 42-177, 42-187, 42-190, 42-193, 42-206, 42-27 and 42-79 are AJ270389-AJ270405, respectively.
}

(Sanglier et al., 1993). Besides the genus Streptomyces, which has been extensively exploited, members of the other genera are also considered of high interest as potential producers of novel bioactive compounds (Horan, 1994, 1999). Although different procedures have been described for the direct and specific isolation of cultures belonging to many of these groups, certain taxa still remain minor groups among the isolates normally recovered from different environments. In addition, the wide range of morphologies and phenotypes found within strains of the same genus, together with the frequent absence of sporulation characteristics, sometimes hinder an initial rapid and reliable morphological identification of many taxa during routine isolation.

Within the family Pseudonocardiaceae, the genus Saccharomonospora represents a minor component 
which apparently shows little distribution in the environment, according to the numbers of isolates normally obtained with traditional isolation methods, when compared to other taxa (Embley, 1992). The genus Saccharomonospora was first described for thermophilic actinomycetes producing a greyish-green aerial mycelium bearing single spores (Nonomura \& Ohara, 1971). They share with other Pseudonocardiaceae the absence of mycolic acids and have cell wall type IV (meso-diaminopimelic acid, arabinose and galactose) (Embley et al., 1988a, b). There are currently four validly published species, the original type species Saccharomonospora viridis (Nonomura \& Ohara, 1971), which includes the former species Saccharomonospora internatus now considered to be a synonym (Greiner-Mai et al., 1988), and the species Saccharomonospora azurea (Runmao, 1987), Saccharomonospora cyanea (Runmao et al., 1988) and Saccharomonospora glauca (Greiner-Mai et al., 1988). The species 'Saccharomonospora caesia', previously described as Micropolyspora caesia, has not been validly published and has recently been shown to be a synonym of Saccharomonospora azurea (Yoon et al., 1999). Other described Saccharomonospora strains include the species Saccharomonospora yunnanensis and more recently the validly published species Saccharomonospora xinjiangensis (Jin et al., 1998). Although thermophilic isolates have been frequently isolated from natural self-heating habitats (compost, mouldy hay, manure and decomposing plant material), mesophilic strains have also been obtained from different soils and stream and lake sediments (Embley, 1992).

Recent phylogenetic analyses of the genus Saccharomonospora, based on similarities of ribosomal gene sequences (Kim et al., 1995; Ruan et al., 1994), have shown the homogeneity of this genus and it has been confirmed as a distinct phyletic line of descent within the family Pseudonocardiaceae. More recently, study of the interspecific relationships based on the comparison of ribosomal internal transcribed spacers (ITSs) has shown the species diversity that can be found among this apparently homogeneous taxon and the usefulness of $16 \mathrm{~S}-23 \mathrm{~S}$ and $23 \mathrm{~S}-5 \mathrm{~S}$ sequences for classification and identification of new Saccharomonospora strains (Yoon et al., 1997a).

An alternative approach to the traditional isolation and identification methods of members of the genus Saccharomonospora would require not only a better knowledge of their distribution and dependence on their occurrence according to the environmental conditions, but the development of new detection and identification techniques based on precise genotypic information that is not influenced by cultivation conditions. Frequently, classical methods have failed to describe completely the natural composition of certain microbial communities from which only the cultivable micro-organisms can be identified (McVeigh et al., 1995). The advances in nucleic acid techniques, based on data derived from the comparative analysis of the ribosomal gene sequences, have allowed the development of powerful tools that can be applied to the study of micro-organisms (Fox \& Stackebrandt, 1987; Ludwig \& Schleifer, 1994; Kim et al., 1995; Yoon et al., 1996a, 1997b). In addition to the phylogenetic analyses derived from the study of the $16 \mathrm{~S}$ rRNA molecule, the great variation in the regional sequence conservation of this molecule can also be exploited as a reliable tool to develop specific probes to be applied at different taxonomic levels (Stackebrandt et al., 1991; Stahl \& Amann, 1991; McVeigh et al., 1995). The use of specific probes as selective amplification primers offers an alternative approach to the rapid identification of large numbers of strains under study (Mehling et al., 1995; Yoon et al., 1996b). Although species-specific probes have also been described for a large number of relevant micro-organisms, their use is restricted to identification at the species level. The application and usefulness of genusspecific primers for the rapid identification of members of two frequently occurring genera of the family have already been shown (Morón et al., 1999). This work has focused on the search for genus-specific probes for the genus Saccharomonospora which can then be applied to the direct detection and to one-step molecular identification of strains of this taxon.

\section{METHODS}

Bacterial strains. The bacterial reference strains used in this study are listed in Table 1; all strains were grown on YMG $(0.4 \%$ glucose, $0.4 \%$ yeast extract and $1.0 \%$ malt extract) agar and brain-heart agar (Difco) at $28^{\circ} \mathrm{C}$, except for the thermophilic strains, which were grown at $50{ }^{\circ} \mathrm{C}$.

Wild-type Saccharomonospora isolates were obtained following standard dilution platings of soils on $\mathrm{R} 8$ agar medium at $50{ }^{\circ} \mathrm{C}$ (Amner et al., 1989). Soils tested were selected from diverse geographical origins and habitats (Table 2).

Design of oligonucleotide primers. Sequence comparison and analysis were carried out using programs from the University of Wisconsin GCG package (version 7.2, September, 1994). The following $16 \mathrm{~S}$ rRNA/DNA sequences, obtained from GenBank, were studied for the design of the primers: X76953, Actinokineospora riparia IFO $14541^{\mathrm{T}}$; X54287, Actinopolyspora halophila ATCC 27976 ${ }^{\mathrm{T}}$; Z22730, Actinopolyspora mortivallis JCM 7550 ${ }^{\mathrm{T}}$; X53199, Amycolatopsis azurea NRRL $11412^{\mathrm{T}}$; X53200, Amycolatopsis fastidiosa ATCC 31181 ${ }^{\mathrm{T}}$; X76957, Amycolatopsis mediterranei ATCC $13685^{\mathrm{T}}$; X54274, Amycolatopsis methanolica NCIB $11946^{\mathrm{T}}$; X81573, Amycolatopsis orientalis DSM 43187; X76958, Amycolatopsis orientalis subsp. orientalis DSM 40040 ${ }^{\mathrm{T}}$; X53191, Kibdelosporangium aridum subsp. aridum ATCC 39323 ${ }^{\mathrm{T}}$; X76954, Pseudonocardia alni Ac-901; X54288, Pseudonocardia autotrophica DSM 535 ; X76955, Pseudonocardia hydrocarbonoxydans DSM 43281 ${ }^{\mathrm{T}}$; X55609, 'Pseudonocardia nitrificans' DSM 46012=IFAM 379; X55608, Pseudonocardia petroleophila DSM 655 $=$ IFAM $78^{\mathrm{T}}$; X76956, Pseudonocardia saturnea DSM 43195 ${ }^{\mathrm{T}}$; X76959, Pseudonocardia compacta DSM 43592 ${ }^{\mathrm{T}}$; Z14111, Pseudonocardia halophobica DSM 43089 ; X53195, Pseudonocardia thermophila ATCC 19285 ${ }^{\mathrm{T}}$; Z38017, Saccharomonospora azurea Na-128 ; X76960, 'Saccharomonospora caesia' INMI 19125 ; Z30819, 'Saccharomonospora caesia' DSM 43068; Z38018, Saccharomonospora cyanea K168 ${ }^{\mathrm{T}}$; 
Z38003, Saccharomonospora glauca DSM 43769 ${ }^{\mathrm{T}}$; Z38007, Saccharomonospora viridis NCIB 9602; X54286, Saccharomonospora viridis ATCC 15386 ${ }^{\mathrm{T}}$; Z38021, Saccharomonospora viridis, E. Greiner-Mai, R25; X76961, Saccharomonospora sp. A1206; Z38004, Saccharomonospora sp., J. S. Ruan, 350; Z38022, Saccharomonospora sp., A. J. McCarthy; Z38023, Saccharomonospora sp., S. B. Kim; Z38017, Saccharomonospora sp., S. B. Kim; Z38005, Saccharomonospora sp., S. B. Kim; Z38006, Saccharomonospora sp., S. B. Kim; Z38024, Saccharomonospora sp., S. B. Kim; AF0056710, Saccharomonospora xinjiangensis XJ-54 ${ }^{\mathrm{T}}$; X53198, Saccharopolyspora erythraea NRRL 2338 X76962, Saccharopolyspora gregorii NCIB $12823^{\mathrm{T}}$; X53196, Saccharopolyspora hirsuta subsp. hirsuta ATCC $27875^{\mathrm{T}}$; X53197, Saccharopolyspora hordei A54 ${ }^{\mathrm{T}}$; X53194, Saccharopolyspora rectivirgula ATCC $33515^{\mathrm{T}}$; X76967, Saccharopolyspora sp. A215; X53193, Saccharothrix australiensis ATCC $31497^{\mathrm{T}}$; X76963, Saccharothrix coeruleofusca DSM 43679 ; X76964, Saccharothrix longispora DSM 43749 ${ }^{\mathrm{T}}$; X76965, Saccharothrix mutabilis subsp. capreolus DSM 40225 ; X76966, Saccharothrix mutabilis subsp. mutabilis DSM 43853 ; X53163, Streptomyces albus subsp. albus DSM 40313 ${ }^{\mathrm{T}}$; X53162, Streptomyces brasiliensis DSM 43159 ; X53161, Streptomyces diastaticus subsp. diastaticus DSM 40496 ${ }^{\mathrm{T}}$; X53173, Streptomyces lavendulae subsp. lavendulae DSM 2014"; Y00484, 'Streptomyces lividans' TK21; X53170, Streptomyces purpureus DSM $43460^{\mathrm{T}}$; X81574, Streptomyces sp. NRRL 3890; X53168, Streptomyces abikoensis DSM 40831 ${ }^{\mathrm{T}}$; X53164, Streptomyces baldaccii DPDU 0819 ; X53165, Streptomyces cinnamoneus subsp. azacoluta DPDU 0074 ${ }^{\mathrm{T}}$; X 53171, Streptomyces cinnamoneus subsp. cinnamoneus DPDU 0093 ${ }^{\mathrm{T}}$; X53167, Streptomyces ladakanum var. ladakanum DSM 40587T X53172, 'Streptomyces luteoreticuli' DPDU 0081; X79323, Streptomyces mashuensis DSM 40221 ${ }^{\mathrm{T}}$; X53166, Streptomyces olivoreticuli subsp. cellulophilus DPDU 0278 ${ }^{\mathrm{T}}$; and X53169, Streptomyces salmonis DPDU 0098 ${ }^{\mathrm{T}}$. The genus specificity of oligonucleotides was tested against all DNA sequences available in GenBank with the FASTA program. The melting temperature $\left(T_{\mathrm{m}}\right)$ was estimated using the formulae of Thomas \& Dancis and Lathe (quoted in Stahl \& Amann, 1991). Relative $T_{\mathrm{m}}$ values obtained using $0.3 \mathrm{M}$ as a standard salt concentration helped to design pairs of primers with similarly high melting temperatures. The probabilities of primer-dimer formation and autofolding were also studied in order to keep them as low as possible. The designed oligonucleotides were supplied by Pharmacia Biotech.

DNA extraction. Total genomic DNAs from the different micro-organisms used in this study were recovered and purified as previously described (Innis et al., 1990).

Soil DNA extraction. Total DNA extraction from soils was adapted from a previously described method (Volossiouk et al., 1995). Soil samples $(250 \mathrm{mg})$ were frozen in liquid nitrogen, ground and suspended in $0.5 \mathrm{ml} \mathrm{0.4 \%} \mathrm{(w/v)} \mathrm{skim}$ milk solution (Difco). Soil particles were sedimented by centrifugation for $10 \mathrm{~min}$ at $17500 \mathrm{~g}$. Supernatants $(300 \mu \mathrm{l})$ were mixed with $200 \mu \mathrm{l}$ extraction buffer $(0.66 \%$ SDS, $0.31 \mathrm{M} \mathrm{NaCl}, 110 \mathrm{mM}$ potassium acetate $\mathrm{pH} 5 \cdot 1)$, vortexed and added to $500 \mu \mathrm{l}$ water-saturated phenol. After extraction, supernatants $(400 \mu \mathrm{l})$ were recovered by centrifugation $(15 \mathrm{~min}, 17500 \mathrm{~g})$ and total DNA was precipitated overnight at $-20{ }^{\circ} \mathrm{C}$ by addition of $1 \mathrm{ml}$ ethanol. After a $15 \mathrm{~min}$ centrifugation at $17500 \mathrm{~g}$, DNA was washed with $75 \%$ cold ethanol and finally dissolved in $100 \mu \mathrm{l}$ sterile distilled water.

PCR amplification. DNA preparations were used as template DNA for the Taq polymerase. Reactions were performed in a final volume of $25 \mu$ containing $0.2 \mathrm{mM}$ of each of the four dNTPs (Roche), $0 \cdot 1 \mu \mathrm{M}$ of each primer, $5 \mu$ l of the extracted DNA (1/100 dilution) and 0.5 U Taq polymerase (Appligene) with its appropriate reaction buffer. Controls without bacterial DNA were included for each PCR experiment. Amplifications were performed in a Perkin Elmer Cetus DNA Thermal cycler 480, according to the following profile: 40 cycles of $30 \mathrm{~s}$ at $93^{\circ} \mathrm{C}, 30 \mathrm{~s}$ at $53^{\circ} \mathrm{C}$ and $2 \mathrm{~min}$ at $72^{\circ} \mathrm{C}$, followed by $10 \mathrm{~min}$ at $72{ }^{\circ} \mathrm{C}$. Amplification products were analysed by electrophoresis $\left(0.25 \mathrm{~V} \mathrm{~cm}^{-2}\right)$ in $1.2 \%(\mathrm{w} / \mathrm{v})$ agarose gels stained with ethidium bromide.

PCR fingerprinting. The high-resolution PCR fingerprinting primers that were used were described by Jensen et al. (1993). The primers L1 (5'-CAAGGCATCCACCGT-3') and G1 (5'-GAAGTCGTAACAACG-3') are complementary to conserved regions of the $16 \mathrm{~S}$ and $23 \mathrm{~S}$ rRNA genes and PCR reactions using both primers result in the amplification of the transcribed spacer sequences between the genes. Amplification conditions were as follow: 30 cycles of $0.5 \mathrm{~min}$ at $94{ }^{\circ} \mathrm{C}, 0.5 \mathrm{~min}$ at $58^{\circ} \mathrm{C}$ and $2 \mathrm{~min}$ at $72^{\circ} \mathrm{C}$, followed by a final $10 \mathrm{~min}$ incubation at $72^{\circ} \mathrm{C}$. Negative controls without template DNA were routinely run for all amplifications. PCR reaction products $(10 \mu \mathrm{l})$ were analysed in $4-20 \%$ acrylamide gradient minigels (Novex). Band patterns were compared with the GELCOMPAR software package version 4.1 (Applied Maths). A similarity matrix was generated using the Pearson product-moment and cluster analysis was performed using the unweighted pair group method with arithmetic averages (UPGMA) (Roberts et al., 1998; Vauterin et al., 1996).

DNA sequencing. PCR and purification procedures were as described previously (Yoon et al., 1997a) with 50:1 molar ratio between the primers, obtaining a major amplification product of single-strand DNA directly used for sequencing. The PCR primers 530f and 907r (Lane, 1991) were used for the amplification of DNA fragments containing the hybridization region of primers SM1 and SM2. The $16 \mathrm{~S}-23 \mathrm{~S}$ intergenic spacers were amplified using as PCR primers the oligonucleotides 1497f (5'-GGACGAAGTCGTAACAAGGT-3') and 115r (5'-GGGTTTCCCCATTCGG-3') selected from conserved sequences at the end and beginning of the $16 \mathrm{~S}$ and $23 \mathrm{~S}$ rDNAs, respectively (Lane, 1991). Sequencing was performed using Cy 5'-labelled primers and the Cy Thermo sequenase Dye terminator kit. Sequencing reactions were electrophoresed in an $A L F$ express DNA sequencing instrument (Amersham Pharmacia Biotech). All samples were sequenced at least twice in both directions.

Data analysis. Sequences were assembled using the GCG Fragment Assembly System (Program Manual for the Wisconsin Package, version 8). Alignments of the 16S-23S spacer region were performed using the multiple alignment program CLUSTAL W (Thompson et al., 1994; IntelliGenetics). The percentage of sequence homology was calculated with DISTANCES from the GCG package.

The phylogenetic analysis was completed with $16 \mathrm{~S}-23 \mathrm{~S}$ ITS sequences of Saccharomonospora spp. type strains previously reported (Yoon et al., 1997a). These 16S-23S ITS sequences were: Saccharomonospora cyanea (U73402), Saccharomonospora azurea (U73397), 'Saccharomonospora caesia' (U73428, U73400, U73410, U73422, U73430, U73432, U73440), Saccharomonospora sp. (U73408), Saccharomonospora viridis (U73426, U73412, U73414, U73420, U73434, U73436) and Saccharomonospora glauca (U73404, U73406, U73416, U73418, U73424, U73438).

Phylogenetic analysis of the aligned 16S-23S ITS sequences was performed using the maximum-parsimony analysis with 
Table 1. Reference strains used in this study and results obtained from selective $P C R$ amplification with SM1/SM2

\begin{tabular}{|c|c|c|}
\hline Species & Strain designation & Amplification result* \\
\hline \multicolumn{3}{|l|}{ Actinopolyspora } \\
\hline 'Actinopolyspora thermovinacea' & ATCC 35862 & 0 \\
\hline \multicolumn{3}{|l|}{ Amycolatopsis } \\
\hline Amycolatopsis azurea & DSM $43854^{\mathrm{T}}$ & 0 \\
\hline Amycolatopsis fastidiosa & $\operatorname{ATCC} 31181^{\mathrm{T}}$ & 0 \\
\hline Amycolatopsis mediterranei & ATCC $13685^{\mathrm{T}}$ & 0 \\
\hline Amycolatopsis methanolica & NCIB $11946^{\mathrm{T}}$ & 0 \\
\hline Amycolatopsis orientalis & NRRL 18098 & 0 \\
\hline Amycolatopsis orientalis & NRRL 18099 & 0 \\
\hline Amycolatopsis orientalis & NRRL 18100 & 0 \\
\hline Amycolatopsis orientalis subsp. orientalis & NRRL 2452 & 0 \\
\hline Amycolatopsis orientalis subsp. orientalis & ATCC 21425 & 0 \\
\hline Amycolatopsis orientalis subsp. orientalis & DSM $40040^{T}$ & 0 \\
\hline Amycolatopsis rugosa & ATCC $43014^{\mathrm{T}}$ & 0 \\
\hline Amycolatopsis sulphurea & NRRL $2822^{\mathrm{T}}$ & 0 \\
\hline \multicolumn{3}{|l|}{ Kibdelosporangium } \\
\hline Kibdelosporangium aridum subsp. aridum & ATCC $39323^{\mathrm{T}}$ & 0 \\
\hline Kibdelosporangium aridum subsp. largum & ATCC $39922^{\mathrm{T}}$ & 0 \\
\hline \multicolumn{3}{|l|}{ Prauserella } \\
\hline Prauserella rugosa & ATCC $43014^{\mathrm{T}}$ & 0 \\
\hline \multicolumn{3}{|l|}{ Pseudonocardia } \\
\hline Pseudonocardia autotrophica & ATCC $19727^{\mathrm{T}}$ & 0 \\
\hline Pseudonocardia autotrophica & DSM 43103 & 0 \\
\hline Pseudonocardia autotrophica & DSM 43098 & 0 \\
\hline Pseudonocardia compacta & ATCC $35407^{\mathrm{T}}$ & 0 \\
\hline Pseudonocardia halophobica & DSM $43089^{\mathrm{T}}$ & 0 \\
\hline Pseudonocardia hydrocarbonoxydans & NRRL B-16171 & 0 \\
\hline 'Pseudonocardia nitrificans' & DSM 46012 & 0 \\
\hline Pseudonocardia petroleophila & DSM $43193^{\mathrm{T}}$ & 0 \\
\hline Pseudonocardia saturnea & NRRL B-16172 & 0 \\
\hline Pseudonocardia thermophila & ATCC $19285^{\mathrm{T}}$ & 0 \\
\hline \multicolumn{3}{|l|}{ Saccharomonospora } \\
\hline Saccharomonospora azurea & ATCC $43670^{\mathrm{T}}$ & 1 \\
\hline 'Saccharomonospora caesia' & ATCC 49227 & 1 \\
\hline Saccharomonospora cyanea & ATCC $43724^{\mathrm{T}}$ & 1 \\
\hline Saccharomonospora glauca & DSM $43769^{\mathrm{T}}$ & 1 \\
\hline 'Saccharomonospora internatus' & ATCC 33517 & 1 \\
\hline Saccharomonospora viridis & ATCC 15345 & 1 \\
\hline Saccharomonospora viridis & ATCC $15386^{\mathrm{T}}$ & 1 \\
\hline \multicolumn{3}{|l|}{ Saccharopolyspora } \\
\hline Saccharopolyspora erythraea & NRRL $2338^{\mathrm{T}}$ & 0 \\
\hline Saccharopolyspora gregorii & NCIB $12823^{\mathrm{T}}$ & 0 \\
\hline Saccharopolyspora hirsuta subsp. hirsuta & ATCC 27876 & 0 \\
\hline Saccharopolyspora hirsuta subsp. hirsuta & NRRL B5792 & 0 \\
\hline Saccharopolyspora hirsuta subsp. kobensis & ATCC $20501^{\mathrm{T}}$ & 0 \\
\hline Saccharopolyspora hordei & NCIB $12824^{\mathrm{T}}$ & 0 \\
\hline Saccharopolyspora rectivirgula & ATCC 15347 & 0 \\
\hline Saccharopolyspora rectivirgula & ATCC $33515^{\mathrm{T}}$ & 0 \\
\hline Saccharopolyspora spinosa & NRRL 18537 & 0 \\
\hline Saccharopolyspora spinosa & ATCC $49460^{\mathrm{T}}$ & 0 \\
\hline Saccharopolyspora taberi & NRRL $16173^{\mathrm{T}}$ & 0 \\
\hline \multicolumn{3}{|l|}{ Saccharothrix } \\
\hline Saccharothrix aerocolonigenes & ATCC 39243 & 0 \\
\hline Saccharothrix aerocolonigenes & NRRL B3298 & 0 \\
\hline Saccharothrix cryophilis & NRRL B-16238 & 0 \\
\hline Saccharothrix flava & DSM $43885^{\mathrm{T}}$ & 0 \\
\hline
\end{tabular}


Table 1 (cont.)

\begin{tabular}{|c|c|c|}
\hline Species & Strain designation & Amplification result* \\
\hline Saccharothrix longispora & DSM $43749^{\mathrm{T}}$ & 0 \\
\hline Saccharothrix mutabilis subsp. capreolus & DSM $40225^{\mathrm{T}}$ & 0 \\
\hline Saccharothrix mutabilis subsp. mutabilis & DSM $43853^{\mathrm{T}}$ & 0 \\
\hline Saccharothrix syringae & DSM $43886^{\mathrm{T}}$ & 0 \\
\hline Saccharothrix waywayandensis & NRRL B-16159 & 0 \\
\hline \multicolumn{3}{|l|}{ Actinokineospora } \\
\hline Actinokineospora riparia & NRRL B-16432 & 0 \\
\hline \multicolumn{3}{|l|}{ Other non-related genera } \\
\hline Actinomadura sp. & MA 6867 & 0 \\
\hline Actinomadura hibisca & ATCC $53557^{\mathrm{T}}$ & 0 \\
\hline Actinomadura pusilla & ATCC $27296^{\mathrm{T}}$ & 0 \\
\hline Kitasatosporia setalba & ATCC $33774^{\mathrm{T}}$ & 0 \\
\hline Micromonospora echinospora subsp. pallida & NRRL $2996^{\mathrm{T}}$ & 0 \\
\hline Streptomyces avermitilis & ATCC 31267 & 0 \\
\hline Streptomyces cattleya & NRRL 8057 & 0 \\
\hline 'Streptomyces hygroscopicus subsp. ascomyceticus' & MA 6572 & 0 \\
\hline Streptomyces hygroscopicus subsp. hygroscopicus & ATCC $27438^{\mathrm{T}}$ & 0 \\
\hline 'Streptomyces hygroscopicus subsp. rapamyceticus' & NRRL 5491 & 0 \\
\hline Streptomyces tsukubaensis & MA 6492 & 0 \\
\hline
\end{tabular}

* Amplification results are as follows: (1) represents a band of the expected size (266 bp); and (0) represents the absence of amplification products.

Table 2. Wild-type isolates of Saccharomonospora sp. used in this study

\begin{tabular}{|c|c|c|}
\hline Strain no. & Country & Substrate and origin \\
\hline $\begin{array}{l}42-14,42-15 \dagger, 42-78 *, 42-79 \dagger, 42-159,42-160,42-161 * \dagger, 42-162 * \dagger \\
42-163,42-164,42-165,42-166 \dagger, 42-167,42-168 \dagger, 42-169 \dagger, 42-170\end{array}$ & Sri Lanka & Soil 1 , this study \\
\hline $42-17^{*} \dagger, 42-86^{*}$ & Sri Lanka & Soil 2, this study \\
\hline $42-82,42-83$ & Sri Lanka & Soil 3 , this study \\
\hline $42-27 * \dagger, 42-96$ & Senegal & Soil 4 , this study \\
\hline $42-106,42-188,42-189,42-190 * \dagger$ & Mexico & Soil 5 , this study \\
\hline $42-147 * \dagger$ & Mexico & Soil 6 , this study \\
\hline $42-157 * \dagger, 42-187 \dagger$ & Mexico & Soil 7, this study \\
\hline $\begin{array}{l}42-146^{*}, 42-171,42-172,42-173,42-174,42-175 \dagger, 42-176,42-177 \dagger \\
42-191,42-192,42-193^{*} \dagger, 42-194,42-195,42-196,42-197^{*}, 42-198, \\
42-199,42-200,42-201,42-202,42-205,42-206 \dagger\end{array}$ & Mexico & Soil 8 , this study \\
\hline $42-178,42-179,42-180,42-181 *, 42-182,42-183$ & Costa Rica & Soil 9, this study \\
\hline $12-82 *$ & Venezuela & Soil, laboratory collection \\
\hline $02-103 *$ & Spain & $\begin{array}{l}\text { Dry seaweed, } \\
\text { laboratory collection }\end{array}$ \\
\hline $10-150$ & Spain & $\begin{array}{l}\text { Decomposing barley, } \\
\text { laboratory collection }\end{array}$ \\
\hline
\end{tabular}

* Strains partially sequenced in the $16 \mathrm{~S}$ rDNA annealing region of primers SM1/SM2.

$\uparrow$ Strains sequenced in their 16S-23S rDNA ITS region.

the heuristic search algorithm of the phylogenetic analysis using parsimony (PAUP) program 3.1.1 (Swofford, 1993), with gaps treated as missing data. The heuristic-search algorithm provides an efficient approach to find all the most parsimonious trees. Data were resampled with 1000 boot- strap replicates (Felsenstein, 1985) by using the heuristic search option of PAUP. The percentage of bootstrap replicates that yielded each grouping was used as a measure of statistical confidence. A grouping found on $95 \%$ bootstrap replicates was considered to be statistically significant. 


\section{RESULTS AND DISCUSSION}

In this work, the design of a pair of genus-specific primers for the selective amplification of the 16S rDNA region of the genus Saccharomonospora and their use for the detection of members of the genus in environmental samples are described. The search for conserved sequences within this genus was based on the comparative analysis of the variable regions of the known 16S rRNA sequences. The strains listed in Methods include representatives from different members of the family Pseudonocardiaceae as well as the related genera Saccharothrix and Actinokineospora. Sequences from Streptomyces strains were also included in the analysis in order to rule out any homology between sequences of strains of Saccharomonospora and representatives of the genus Streptomyces.

The analysis was performed by means of alignment of all these sequences that allowed the localization of six variable regions in the $16 \mathrm{~S}$ rDNA sequence corresponding to nt positions 170-230, 430-580, 560-640, $790-830,960-1020$ and 1090-1130 of the Streptomyces ambofaciens 16S rDNA gene (Pernodet et al., 1989). Three of these sequences (positions 170-230, 960-1020 and 1090-1120, respectively) correspond in fact to the alpha, beta and gamma regions previously described for the genus Streptomyces (Stackebrandt et al., 1992). The search for genus-specific sequences was focussed on these six variable regions and, from the beginning, the region 790-830 appeared to be one of the most promising, given the high sequence conservancy found among the members of the genus. This homology was high enough to consider the design of genus-specific primers for the sequences available for all species of the genus. The region around nt 560-640 also showed an appropriate degree of conservation within the genus. In contrast, analysis of the sequences in the other hypervariable regions showed such a low homology within the genus that these sequences can only be used at the species or even strain level. The regions containing species-specific signature nucleotides have been used to define species-specific primers (Yoon et al., 1996b).

\section{Specific primers for the genus Saccharomonospora}

When nt 790-830 of the 16S rRNA region from different representatives of the genus Saccharomonospora was examined in detail, it was observed that not all positions were unique for all the members of this genus; some positions were also shared by other genera of the family Pseudonocardiaceae. Within this region, a short sequence of $16 \mathrm{nt}$ was identified that harboured the highest number of conserved positions in the genus at nt 811-826; it presented one single base change $\mathrm{T}: \mathrm{G}$ at nt 816 in the case of the type strain of Saccharomonospora viridis ATCC $15386^{\mathrm{T}}$ (X54286). The sequence of $16 \mathrm{nt}$ was used as the basis for the design of the reverse primer SM1 (5'-ACGGCACGGGACACGTGMACAGC-3') that included the degeneration in this position $(\mathrm{M}=\mathrm{C}: \mathrm{A})$ and that was extended to $23 \mathrm{nt}$ by addition of five conserved nucleotides to its $3^{\prime}$ end to stabilize hybridization. According to its sequence, the primer SM1 presented a very high $T_{\mathrm{m}}$ (between 61.18 and $62.96^{\circ} \mathrm{C}$ ).

To define a specific oligonucleotide to be used as a forward PCR primer, the upstream variable sequences were studied and the region included within positions 560-640 was selected. In this case, identical sequences were found for all the different strains of Saccharomonospora studied. Again, the most specific sequence included only $18 \mathrm{nt}$ between positions 572 and 589 and presented a very low $T_{\mathrm{m}}$ which was not compatible with the high $T_{\mathrm{m}}$ of the primer SM1. The sequence was elongated to $22 \mathrm{nt}$ including five bases of well-conserved positions flanking this region (5'-CGTCTGCCGTGAAAACCTGCGGC-3'). This elongation stabilized the primer by increasing its $T_{\mathrm{m}}$ to $61 \cdot 18{ }^{\circ} \mathrm{C}$, which is in the same range as that of primer SM1. According to the sequence, the expected size of the amplification product using this pair of oligonucleotides was 266 bp.

To test the genus specificity of this pair of oligonucleotides, PCR assays were performed using template DNAs isolated from a series of reference strains of 13 different genera (Table 1). Using the pair of primers SM1/SM2 and an annealing temperature of $53{ }^{\circ} \mathrm{C}$, the specific amplification product of $266 \mathrm{bp}$ was obtained from all strains of the six different species of the genus Saccharomonospora tested [Saccharomonospora azurea, 'Saccharomonospora caesia', Saccharomonospora cyanea, Saccharomonospora glauca, 'Saccharomonospora internatus' and Saccharomonospora viridis (two strains)]. No amplification products were detected in control experiments performed with DNAs from all the other bacterial strains analysed (Table 1, Fig. 1). These results are in accordance with the sequences published most recently for many of the strains tested that complement exactly the sequence of the primers. There is only one exception with the sequence of the strain of Saccharomonospora cyanea $\mathrm{K} 168^{\mathrm{T}}$ in the region corresponding to the sequence of SM1. In this case, one difference was found at position 821 ( $\mathrm{T}: \mathrm{C}$ ) that apparently does not affect the amplification result with this strain.

To confirm that this lack of amplification with the reference strains other than Saccharomonospora strains was not due to the poor condition of the DNA extracts, amplification reactions were performed with previously published primers, designed specifically for actinomycetes (F243) and for Gram-positive bacteria (R513), using the conditions recommended (Heuer et al., 1997). The expected amplification product of $271 \mathrm{bp}$ was observed in all strains of actinomycetes tested. The specificity of the pair of primers SM1/SM2 was tested at different annealing temperatures and it was found that an increase of this temperature up to $72{ }^{\circ} \mathrm{C}$ still allowed amplification from at least the strains of Saccharomonospora azurea and Saccharomonospora viridis. 


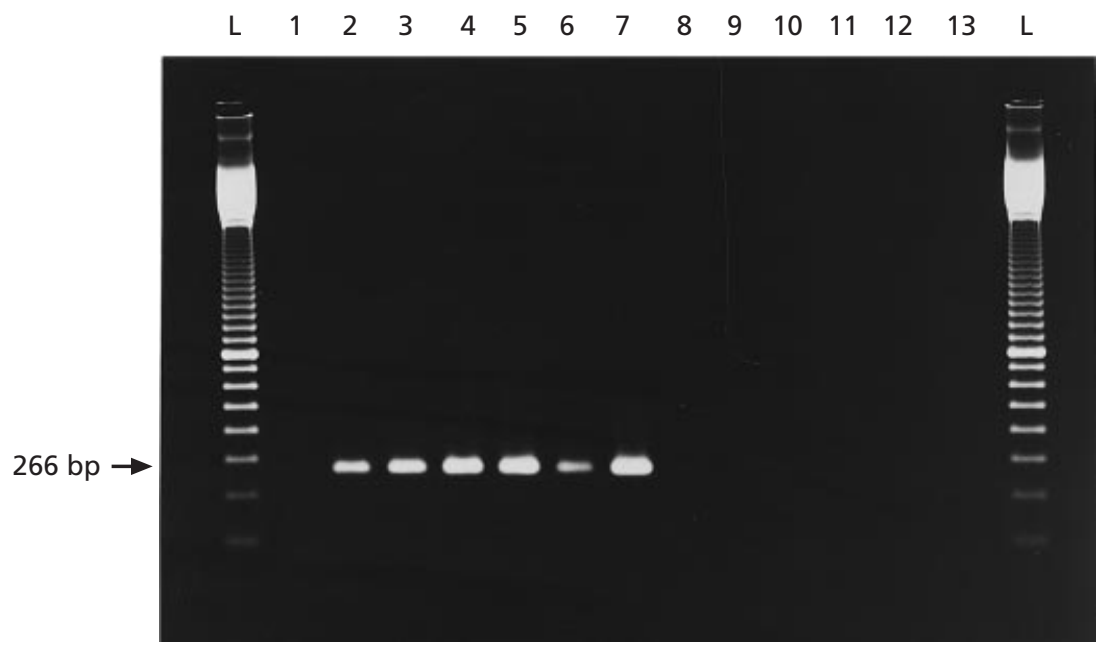

Fig. 1. Agarose gel electrophoresis of $P C R$ products: selective amplification of the $266 \mathrm{bp}$ fragment with primers SM1/SM2. Lanes: 1, control reaction without DNA; 2, Saccharomonospora azurea ATCC $43670^{\top}$; 3, 'Saccharomonospora caesia' ATCC 49227; 4, Saccharomonospora cyanea ATCC $43724^{\mathrm{T}}$; 5, Saccharomonospora glauca DSM $43769^{\top}$; 6, 'Saccharomonospora internatus' ATCC 33517 ; 7, Saccharomonospora viridis ATCC $15386^{\top} ;$ 8, Pseudonocardia thermophila ATCC $19285^{\top} ; 9$, Amycolatopsis orientalis subsp. orientalis DSM $40040^{\top}$; 10, Saccharopolyspora hirsuta subsp. hirsuta NRRL $\mathrm{B}^{5} 792^{\top} ;$ 11, Saccharothrix syringae DSM $43886^{\top}$; 12, Actinomadura hibisca ATCC $53557^{\mathrm{T}}$; 13, Streptomyces avermitilis ATCC 31267; L, molecular mass marker (100 bp ladder; Pharmacia Biotech).

These results show that the pair of primers SM1/SM2 allow the identification of all the tested strains belonging to the genus, in spite of the small differences observed in their sequences. The pair SM1/SM2 is genus-specific at a low annealing temperature $\left(53{ }^{\circ} \mathrm{C}\right)$. These low stringency conditions used in the PCR reaction are not selective enough to distinguish between sequences of the same genus which differ in just one nucleotide, therefore providing a very accurate tool for the detection and identification of members of this genus.

To rule out a possible PCR amplification with primers SM1/SM2 of 16S rDNA sequences other than those of the genera already tested, a FASTA analysis was also performed against all the DNA sequences available in GenBank. Results confirmed the complete homology of both primers only with sequences of Saccharomonospora strains.

\section{Isolation and identification of wild-type isolates}

Once the genus specificity of the oligonucleotides was verified on the reference strains from culture collections, the probes were tested as detection tools for new members of this genus. The isolation of wild-type strains of the genus Saccharomonospora was attempted from a series of 50 soils obtained from diverse geographical origins; 57 wild-type isolates were finally obtained from only nine of the 50 soil samples tested (Table 2). All these strains, tentatively assigned to the genus Saccharomonospora on the basis of their microscopic morphological characters, were positively amplified with the pair of genus-specific primers producing an amplification product of the expected size.

To determine that the strains positively identified with the pair of primers effectively corresponded to this genus, a representative subset of 15 wild-type isolates from different origins was selected (strains 12-82,
02-103, 42-17, 42-27, 42-78, 42-86, 42-146, 42-147, $42-157, \quad 42-161,42-162,42-181,42-190,42-193$, 42-197), including two additional strains from the laboratory culture collection (Table 2). The 16S rDNA region between nt 530-907, including the annealing sites of primers SM1 and SM2, was sequenced. All the sequences at positions $811-833$ and 568-590 perfectly matched the sequences of SM1 and SM2, respectively (Table 3). In all cases, it was confirmed that the sequences of wild-type isolates were identical to the sequence of the type species of Saccharomonospora glauca and Saccharomonospora azurea in the SM1 region. The conservancy of the sequences found in wild-type isolates supports the specificity of the primers used for identification of the strains.

\section{PCR detection of Saccharomonospora strains in soil DNAs}

The primers SM1/SM2 were then tested to detect the presence of members of the genus Saccharomonospora directly from soils. Total DNAs were purified from the nine soils that were shown to contain representatives of this genus, as well as from soils that gave negative results in the isolation experiment. A specific amplification product of the expected size was obtained exclusively in the samples that contained Saccharomonospora strains, confirming the ability of this pair of primers to detect the presence of this genus directly from crude extracts of soil DNA.

To evaluate the level of detection of our primers in amplification reactions with crude soil DNA preparations, the lowest concentration of total DNA from Saccharomonospora strains that could be detected by specific PCR amplification in about $10^{-13} \mu \mathrm{g} \mu \mathrm{l}^{-1}$ was estimated initially. The level of detection was not affected by the extraction procedure nor by the presence of exogenous DNA. The same results were observed in competition experiments performed with Saccharomonospora DNA that was co-extracted with 
Table 3. Partial $16 \mathrm{~S}$ rDNA sequences of the wild-type isolates assigned to the genus Saccharomonospora

\begin{tabular}{|c|c|c|c|c|c|}
\hline \multirow[t]{2}{*}{ Strain } & \multicolumn{4}{|c|}{ Nucleotide sequence region } & \multirow[t]{2}{*}{ EMBL no. } \\
\hline & & $566-588$ & 811-833 & & \\
\hline & $\mathrm{SM} 2$ & CGTCTGCCGTGAAAACCTGCGGC & GCTGTKCACGTGTCCCGTGCCGT & $\mathrm{SM} 1 *$ & \\
\hline $12-82$ & & CGTCTGCCGTGAAAACCTGCGGC & GCTGTTCACGTGTCCCGTGCCGT & & AJ270373 \\
\hline $02-103$ & & CGTCTGCCGTGAAAACCTGCGGC & GCTGTTCACGTGTCCCGTGCCGT & & AJ270374 \\
\hline $42-146$ & & CGTCTGCCGTGAAAACCTGCGGC & GCTGTTCACGTGTCCCGTGCCGT & & AJ270375 \\
\hline $42-147$ & & CGTCTGCCGTGAAAACCTGCGGC & GCTGTTCACGTGTCCCGTGCCGT & & AJ270376 \\
\hline $42-157$ & & CGTCTGCCGTGAAAACCTGCGGC & GCTGTTCACGTGTCCCGTGCCGT & & AJ 270377 \\
\hline $42-161$ & & CGTCTGCCGTGAAAACCTGCGGC & GCTGTTCACGTGTCCCGTGCCGT & & AJ270378 \\
\hline $42-162$ & & CGTCTGCCGTGAAAACCTGCGGC & GCTGTTCACGTGTCCCGTGCCGT & & AJ270389 \\
\hline $42-17$ & & CGTCTGCCGTGAAAACCTGCGGC & GCTGTTCACGTGTCCCGTGCCGT & & AJ 270380 \\
\hline $42-182$ & & CGTCTGCCGTGAAAACCTGCGGC & GCTGTTCACGTGTCCCGTGCCGT & & AJ270381 \\
\hline $42-187$ & & CGTCTGCCGTGAAAACCTGCGGC & GCTGTTCACGTGTCCCGTGCCGT & & AJ270382 \\
\hline $42-190$ & & CGTCTGCCGTGAAAACCTGCGGC & GCTGTTCACGTGTCCCGTGCCGT & & AJ270383 \\
\hline $42-193$ & & CGTCTGCCGTGAAAACCTGCGGC & GCTGTTCACGTGTCCCGTGCCGT & & AJ270384 \\
\hline $42-27$ & & CGTCTGCCGTGAAAACCTGCGGC & GCTGTTCACGTGTCCCGTGCCGT & & AJ270385 \\
\hline $42-78$ & & CGTCTGCCGTGAAAACCTGCGGC & GCTGTTCACGTGTCCCGTGCCGT & & AJ270386 \\
\hline $42-82$ & & CGTCTGCCGTGAAAACCTGCGGC & GCTGTTCACGTGTCCCGTGCCGT & & AJ270387 \\
\hline $42-86$ & & CGTCTGCCGTGAAAACCTGCGGC & GCTGTTCACGTGTCCCGTGCCGT & & AJ270388 \\
\hline
\end{tabular}

* For the best comparison with the sequenced region, complementary sequences are shown for reverse primer SM1.
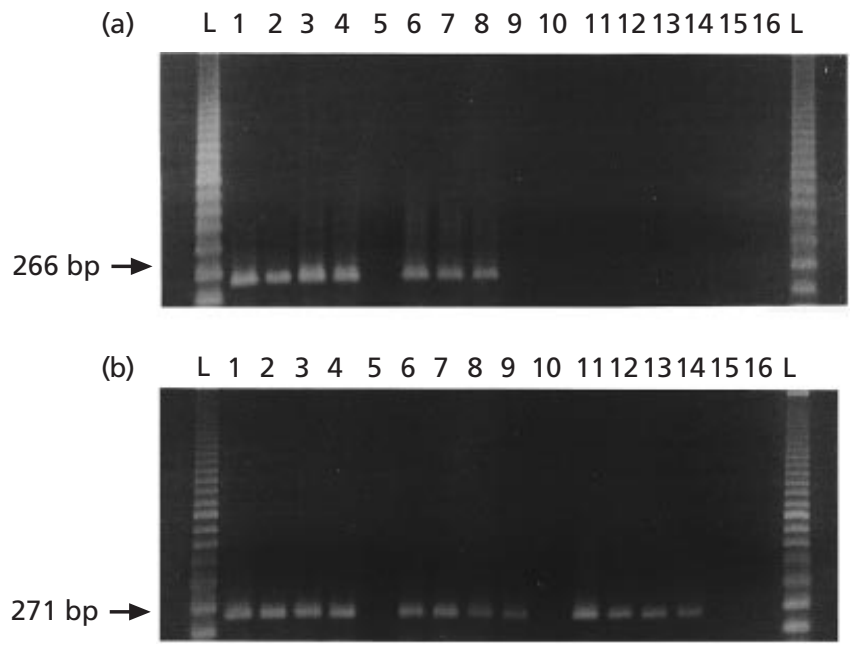

Fig. 2. Agarose gel electrophoresis of $P C R$ products from soil DNA. (a) Selective amplification of the 266 bp fragment using primers SM2/SM1 specific for the genus Saccharomonospora. (b) Selective amplification of the 271 bp fragment using primers F243/R513 specific for actinomycetes and Gram-positive bacteria, respectively. In all cases, serial dilutions of $10^{-4}, 10^{-5}, 10^{-6}, 10^{-7}$ and $10^{-8} \mu \mathrm{g} \mathrm{Il}^{-1}$ soil DNA were used in amplification reactions. Lanes: $1-5$, PCR products from soil no.1 (Sri Lanka); 6-10, PCR products obtained from soil no. 8 (Mexico); 11-15, PCR products obtained from control soil containing actinomycetes other than Saccharomonospora strains; 16, control reaction without DNA; L, molecular mass marker (100 bp ladder; Pharmacia Biotech).

total DNA from different soils that did not produce an amplification product with the probes.

To evaluate the detection range in crude total soil DNA extracts, the minimum soil DNA concentration necessary to detect the presence of this genus was determined with the probes. Serial dilutions of the nine soil DNAs were used in PCR amplification experiments and, in all cases, the minimum concentration required to detect an amplification product was around $10^{-7} \mu \mathrm{g} \mu 1^{-1}$ (Fig. 2).

\section{Diversity of Saccharomonospora isolates}

To determine the diversity of the isolates that, within this genus, could be detected with the use of these oligonucleotides, the existing relationship between our isolates and the reference strains was studied by 

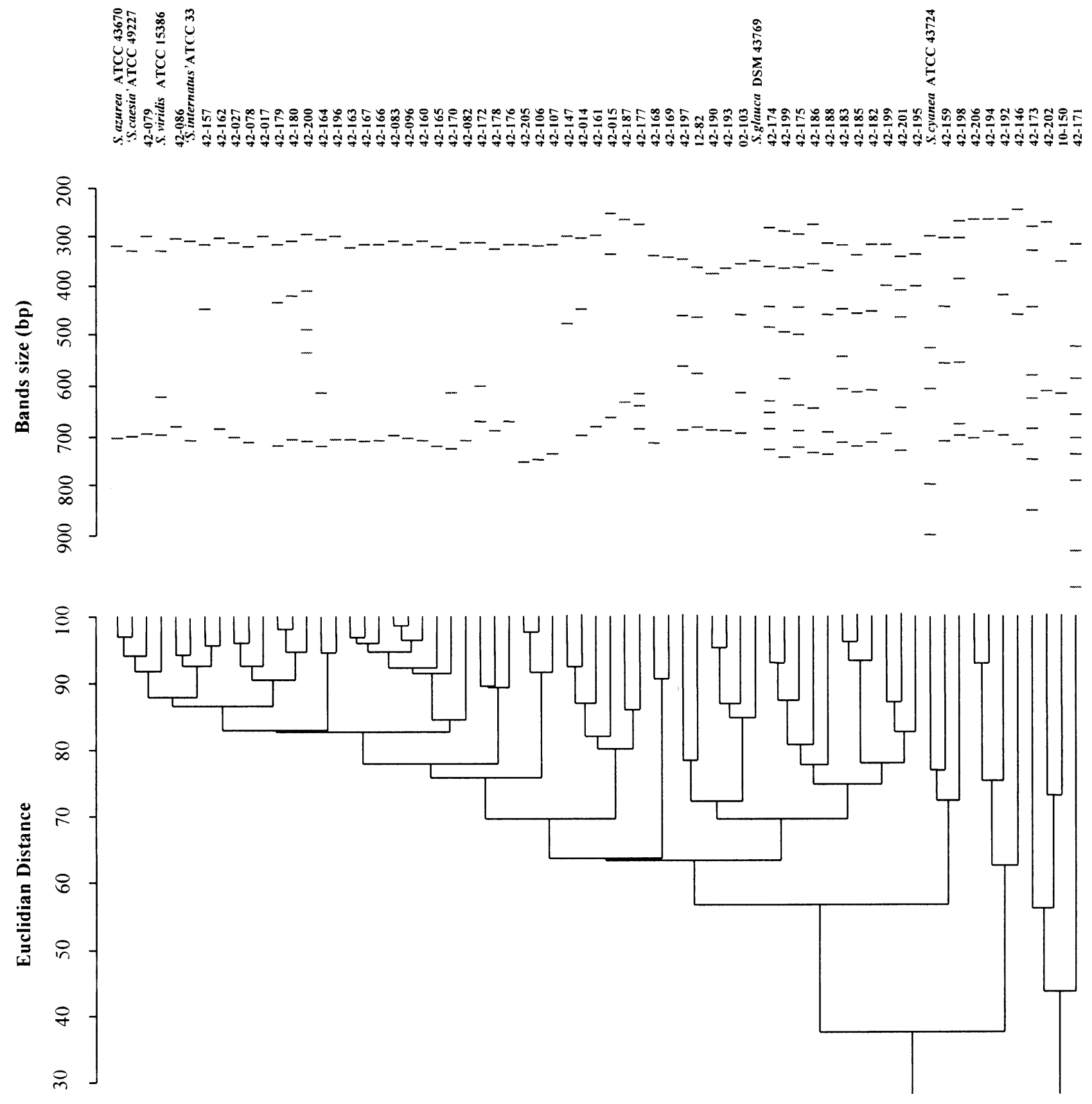

Fig. 3. Cluster analysis of PCR fingerprints showing the diversity of the wild-type isolates of Saccharomonospora using the UPGMA method. The schematic representation of the intergenic 16S-23S amplification patterns obtained with the primers L1/G1 was performed with the GELCOMPAR software package.

analysis of their PCR fingerprinting pattern generated by specific amplification of the $16 \mathrm{~S}-23 \mathrm{~S}$ rDNA ITS. It has been shown that these spacers have a high degree of length and sequence variation at the genus and species level, due in part to variations in the number and type of tRNA sequences (Loughney et al., 1982; Brosius et al., 1981). The high-resolution fingerprinting primers described by Jensen et al. (1993) under the conditions recommended by Hirsch \& Sigmund (1995) were used. The PCR amplification patterns of a group of 66 strains, including six reference strains of Saccharomonospora (Saccharomonospora azurea, Saccharomonospora cyanea, Saccharomonospora viridis, 'Saccharomonospora internatus', Saccharomonospora glauca and 'Saccharomonospora caesia') and a subset of 60 wild-type Saccharomonospora isolates were analysed. Their relationship was established in a dendrogram generated by treatment of the Euclidian distances of the amplification patterns by UPGMA (Fig. 3). 


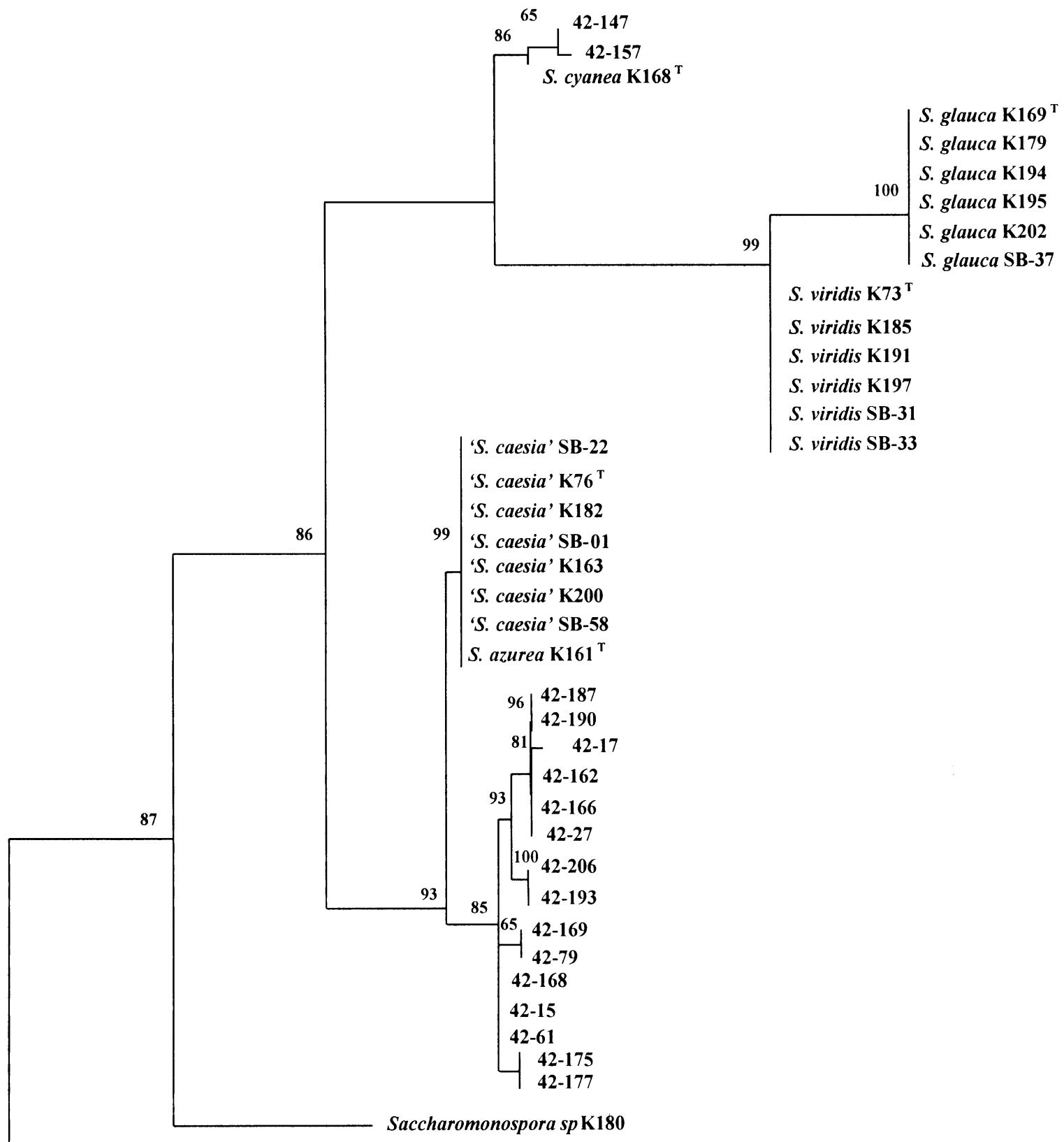

Actinopolyspora halophila JCM $3278^{\mathrm{T}}$

Fig. 4. Phylogenetic analysis of the aligned 16S-23S ITS sequences of the wild-type isolates and reference strains of Saccharomonospora using the maximum-parsimony method in PAUP 3.1.1. The numbers above branches indicate the bootstrap percentage from 1000 bootstrap replicates that was used as a measure of statistical confidence. A grouping found on $95 \%$ bootstrap replicates was considered to be statistically significant. GenBank accession numbers of sequences from the strains of Saccharomonospora included in the analysis are as follows: U73402 (S. cyanea K168 $\left.{ }^{\top}\right)$; U73397 (S. azurea K161'T); U73428 ('S. caesia' K76'); U73400 ('S. caesia' K163); U73410 ('S. caesia' K182); U73422 ('S. caesia' K200); U73430 ('S. caesia' SB-01); U73432 ('S. caesia' SB-22); U73440 ('S. caesia' SB-58); U73408 (Saccharomonospora sp. K180); U73426 (S. viridis K73'); U73412 (S. viridis K185); U73414 (S. viridis K191); U73420 (S. viridis K197); U73434 (S. viridis SB-31); U73436 (S. viridis SB-33); U73404 (S. glauca K169'); U73406 (S. glauca K179); U73416 (S. glauca K194); U73418 (S. glauca K195); U73424 (S. glauca K202); and U73438 (S. glauca SB-37). The tree was rooted with the ITS sequence of Actinopolyspora halophila JCM $3278^{\top}$ (Z46603).

Analysis has shown the existence of four major clusters of strains among our isolates. It was observed that although most of the wild-type isolates of the genus Saccharomonospora are associated with the same main cluster, many strains also appear on separate branches of the dendrogram and do not match any of the clusters defined by the amplification patterns of known species. Clustering analysis based on PCR fingerprints was only used to show the large diversity of new isolates that could be identified to the genus level by 
means of a selective PCR amplification with the genusspecific primers. This fingerprinting pattern was also used to identify the presence of redundant isolates among strains obtained from the same source. With the exception of four clusters of isolates obtained from three different sources that seemed to correspond to identical strains, the remaining cultures appeared as unique strains as they were obtained from different environments.

The use of the PCR fingerprinting has also revealed among many of our isolates the existence of a polymorphism in the size and number of the $16 \mathrm{~S}-23 \mathrm{~S}$ rDNA ITS sequences (Fig. 2). Multiple additional bands of higher molecular mass (above $700 \mathrm{bp}$ ) were obtained as PCR products even under the most stringent amplification conditions tested in the study. The same result was also obtained with the use of alternative PCR primers such as $1497 \mathrm{f}$ and $115 \mathrm{r}$ directed to conserved sequences at the end and beginning of the $16 \mathrm{~S}$ and $23 \mathrm{~S}$ rDNAs, respectively (Lane, 1991); this confirms previous observations (Jensen et al., 1993; Yoon et al., 1997a).

The sequence polymorphism of these spacers has recently been shown to discriminate between different species of the genus Saccharomonospora (Yoon et al., 1997a). The fragment that corresponded to the $16 \mathrm{~S}-23 \mathrm{~S}$ spacer of 17 isolates was sequenced producing single amplification products but with different lengths, and sequence data also show a high level of polymorphism in our isolates. The 16S-23S intergenic spacer regions of the Saccharomonospora wild-type isolates range from a minimum size of $181 \mathrm{bp}$ (isolate 42-157) to a maximum of $192 \mathrm{bp}$ (42-190). The ITS region $5^{\prime}$ and $3^{\prime}$ ends were deduced from the $3^{\prime}$ ends of the $16 \mathrm{~S} \mathrm{rDNAs}$ and the $5^{\prime}$ ends of the $23 \mathrm{~S}$ rDNAs of Saccharomonospora spp. previously reported (Kim et al., 1995; Yoon et al., 1997a). Due to their small size, tRNA-like sequences were not found in the ITS region of any of the Saccharomonospora strains. This is consistent with previous results showing the absence of tRNA genes in the ITS sequences of Saccharomonospora strains, as well as in other actinomycetes (Yoon et al., 1997a). The level of sequence similarity for the $16 \mathrm{~S}-23 \mathrm{~S}$ sequence among wild-type isolates was $87-99 \%$. The most distant relationship of these strains with reference species was found with Saccharomonospora glauca, where similarities were between 77 and $81 \%$. As previously reported, the strains of 'Saccharomonospora caesia' and Saccharomonospora azurea show identical 16S-23S ITS sequences, a result previously used to support the proposal of 'Saccharomonospora caesia' and Saccharomonospora azurea as synonyms (Yoon et al., 1999). A phylogenetic tree based on these 16S-23S ITS sequences was built using the maximum-parsimony method (Fig. 4), showing the inter and intraspecific relationships of the genus Saccharomonospora. As previously described, the four valid species and the strain Saccharomonospora sp. form distinct branches. The strains of Saccharomonospora viridis and Saccharomonospora glauca are more closely related than the synonyms Saccharomonospora azurea/'Saccharomonospora caesia' and Saccharomonospora cyanea, which is the most distant species. The topology of the tree confirms previous works (Yoon et al., 1997a). Wild-type isolates are included in a new cluster clearly separated from reference isolates, with the exception of isolates 42-147 and 42-157, which cluster even more externally, out of the principal branches. The presence of a new cluster of wild-type isolates could suggest the existence of a possible new lineage within the genus. The topology of the tree suggests the presence of a common ancestor for the isolates of 'Saccharomonospora caesia', Saccharomonospora azurea, Saccharomonospora viridis and Saccharomonospora glauca, whereas Saccharomonospora cyanea appears as another evolutionary lineage distant from the rest of the species. The phylogenetic tree was supported by bootstrapping analysis, which shows very high indexes of statistical confidence in branches which include isolates belonging to the same species (Fig. 4).

The sequence polymorphism of the 16S-23S ITS region has been very useful to distinguish between our Saccharomonospora strains. Within this genus, the intraspecific homogeneity of the 16S rDNA gene that has been reported for all species contrasts with the intraspecific differences found in the 16S-23S ITS sequences. These sequences have provided very useful information to evaluate the diversity of wild-type isolates of the genus Saccharomonospora that can be identified with the genus-specific probes.

Our results with reference strains as well as with wildtype isolates validate the specificity of this new pair of primers for $16 \mathrm{~S}$ rDNA sequences of Saccharomonospora strains. The high diversity of the wild-type strains obtained from different habitats supports the usefulness of the application of these tools for the tentative genus assignment of new isolates of this taxon. Finally, their application in the direct detection of members of this genus from environmental DNA has also been shown.

\section{REFERENCES}

Amner, W., Edwards, C. \& McCarthy, A. J. (1989). Improved medium for recovery and enumeration of the farmer's lung organism, Saccharomonospora viridis. Appl Environ Microbiol 55, 2669-2674

Brosius, J., Dul, T. J., Sleeter, D. D. \& Noller, H. F. (1981). Gene organization and primary structure of a ribosomal RNA operon from Escherichia coli. J Mol Biol 148, 107-127.

Embley, T. M. (1992). The family Pseudonocardiaceae. In The Prokaryotes, 2nd edn, pp. 996-1027. Edited by A. Balows, H. G. Trüper, M. Dworkin, W. Harder \& K.-H. Schleifer. New York: Springer.

Embley, T. M., O'Donnell, A. G., Rostron, J. \& Goodfellow, M. (1988a). Chemotaxonomy of wall type IV actinomycetes which lack mycolic acids. J Gen Microbiol 134, 953-960.

Embley, T. M., Smida, J. \& Stackebrandt, E. (1988b). The phylogeny of mycolate-less wall chemotype IV actinomycetes 
and description of the new family Pseudonocardiaceae. Syst Appl Microbiol 11, 44-52.

Felsenstein, J. (1985). Confidence intervals on phylogenies: an approach using the bootstrap. Evolution 39, 783-791.

Fox, G. E. \& Stackebrandt, E. (1987). The application of $16 \mathrm{~S}$ rRNA cataloguing and $16 \mathrm{~S}$ rRNA sequencing in bacterial systematics. Methods Microbiol 19, 405-458.

Greiner-Mai, E., Korn-Wendisch, F. \& Kutzner, H. J. (1988). Taxonomic revision of the genus Saccharomonospora and description of Saccharomonospora glauca sp. nov. Int J Syst Bacteriol 38, 398-405.

Heuer, H., Krsek, M., Baker, P., Smalla, K. \& Wellington, E. M. H. (1997). Analysis of actinomycete communities by specific amplification of genes encoding 16S rRNA and gel-electrophoretic separation in denaturing gradients. Appl Environ Microbiol 63, 3233-3241.

Hirsch, C. F. \& Sigmund, J. M. (1995). Use of polymerase chain reaction (PCR) fingerprinting to differentiate bacteria for microbial products screening. J Ind Microbiol 15, 85-93.

Horan, A. C. (1994). Aerobic Actinomycetes: a continuing source of novel natural products. In The Discovery of Natural Products with Therapeutic Potential, pp. 3-30. Edited by V. P. Gullo. London: Butterworth-Heinemann.

Horan, A. C. (1999). Secondary metabolite production, Actinomycetes, other than Streptomyces. In Encyclopedia of Bioprocess Technology: Fermentation, Biocatalysis and Bioseparation, pp. 2333-2348. Edited by M. C. Flickinger \& S. W. Drew. Chichester: Wiley.

Innis, M. A., Gelfand, D. H., Sninsky, J. J. \& White, T. J. (editors) (1990). PCR Protocols: a Guide to Methods and Applications. San Diego: Academic Press.

Jensen, M. A., Webster, J. A. \& Straus, N. (1993). Rapid identification of bacteria on the basis of polymerase chain reactionamplified ribosomal DNA spacer polymorphisms. Appl Environ Microbiol 59, 945-952.

Jin, X., Xu, I.-H., Mao, P.-H., Hseu, T.-H. \& Jiang, C.-L. (1998). Description of Saccharomonospora xinjiangensis sp. nov. based on chemical and molecular classification. Int J Syst Bacteriol 48 , 1095-1099.

Kim, S.-B., Yoon, J.-H., Kim, H., Lee, S. T., Park, Y.-H. \& Goodfellow, M. (1995). A phylogenetic analysis of the genus Saccharomonospora conducted with 16S rRNA gene sequences. Int J Syst Bacteriol 45, 351-356.

Lane, D. J. (1991). 16S/23S rRNA sequencing. In Nucleic Acid Techniques in Bacterial Systematics, pp. 115-175. Edited by E. Stackebrandt \& M. Goodfellow. Chichester: Wiley.

Loughney, K., Lund, E. \& Dahlberg, J. E. (1982). tRNA genes are found between the $16 \mathrm{~S}$ and $23 \mathrm{~S}$ genes in Bacillus subtilis. Nucleic Acids Res 10, 1607-1624.

Ludwig, S. \& Schleifer, K.-H. (1994). Bacterial phylogeny based on $16 \mathrm{~S}$ and $23 \mathrm{~S}$ rRNA sequence analysis. FEMS Microbiol Rev 15, 155-173.

McVeigh, H. P., Divers, M., Warwick, S., Munro, J. \& Embley, T. M. (1995). Exploration of actinomycetes diversity using ribosomal RNA sequences. In Proceedings of the Ninth International Symposium on the Biology of the Actinomycetes, pp. 253-260. Edited by V. G. Debabov, Y. V. Dudnik \& V. N. Danilenko. Moscow.

Mehling, A., Wehmeier, U. F. \& Piepersberg, W. (1995). Nucleotide sequences of Streptomycete $16 \mathrm{~S}$ ribosomal DNA: towards a specific identification system for Streptomycetes using PCR. Microbiology 141, 2139-2147.
Morón, R., González, I. \& Genilloud, O. (1999). New genusspecific primers for the PCR identification of members of the genera Pseudonocardia and Saccharopolyspora. Int J Syst Bacteriol 49, 149-162.

Nonomura, H. \& Ohara, Y. (1971). Distribution of actinomycetes in soil (X). New genus and species of monosporic actinomycetes. J Ferm Tech 49, 895-903.

Pernodet, J.-L., Boccard, F., Alegre, M.-T., Gagnat, J. \& Guerineau, M. (1989). Organization and nucleotide sequence analysis of a ribosomal RNA gene cluster from Streptomyces ambofaciens. Gene 79, 33-46.

Roberts, P. D., Hodge, N. C., Bouzar, H., Jones, J. B., Stall, R. E., Berger, R. D. \& Chase, A. R. (1998). Relatedness of strains of Xanthomonas fragariae by restriction fragment polymorphism, DNA-DNA reassociation, and fatty acid analysis. Appl Environ Microbiol 64, 3961-3965.

Ruan, J.-S., Lang, Y., Shi, Y., Qu, L. \& Yu, X. (1994). Chemical and molecular classification of Saccharomonospora strains. Int $J$ Syst Bacteriol 44, 704-707.

Runmao, H. (1987). Saccharomonospora azurea sp. nov., a new species from soil. Int J Syst Bacteriol 37, 60-61.

Runmao, H., Lin, C. \& Guizhen, W. (1988). Saccharomonospora cyanea sp. nov. Int J Syst Bacteriol 38, 444-446.

Sanglier, J. J., Haag, H., Huck, T. A. \& Fehr, T. (1993). Novel bioactive compounds from actinomycetes: a short review (1988-1992). Res Microbiol 144, 633-642.

Stackebrandt, E., Witt, D., Kemmerling, C., Kroppenstedt, R. \& Liesack, W. (1991). Designation of streptomycete $16 \mathrm{~S}$ and $23 \mathrm{~S}$ rRNA-based target regions for oligonucleotide probes. Appl Environ Microbiol 57, 1468-1477.

Stackebrandt, E., Liesack, W. \& Witt, D. (1992). Ribosomal RNA and rDNA sequence analyses. Gene 115, 255-260.

Stahl, D. A. \& Amann, R. (1991). Development and application of nucleic acid probes. In Nucleic Acid Techniques in Bacterial Systematics, pp. 205-248. Edited by E. Stackebrandt \& M. Goodfellow. Chichester: Wiley.

Swofford, D. L. (1993). PAUP: phylogenetic analysis using parsimony, version 3.1.1. Washington DC: Laboratory of Molecular Systematics, Smithsonian Institute.

Thompson, J. D., Higgins, D. G. \& Gibson, T. J. (1994). CLUSTAL $\mathrm{W}$ : improving the sensitivity of progressive multiple sequence alignment through sequence weighting position-specific gap penalties and weight matrix choice. Nucleic Acids Res 22, 4673-4680.

Vauterin, L., Yang, P. \& Swings, J. (1996). Utilization of fattyacid methyl-esters for the differentiation of new Xanthomonas species. Int J Syst Bacteriol 46, 298-304.

Volossiouk, T., Rob, E. J. \& Nazar, R. N. (1995). Direct DNA extraction for PCR-mediated assays of soil organisms. Appl Environ Microbiol 61, 3972-3976.

Yoon, J. H., Kim, H., Kim, S. B., Kim, H. J., Kim, W. Y., Lee, S. T., Goodfellow, M. \& Park, Y. H. (1996a). Identification of Saccharomonospora strains by the use of genomic DNA fragments and rRNA gene probes. Int $J$ Syst Bacteriol 46, 502-505.

Yoon, J. H., Lee, S. T., Shin, Y. K., Kim, S.-B., Kim, H.-J., Goodfellow, M. \& Park, Y.-H. (1996b). Rapid identification of Saccharomonospora strains by multiplex PCR using speciesspecific primers within the $16 \mathrm{~S}$ rRNA gene. J Microbiol Methods 27, 89-95.

Yoon, J. H., Lee, S. T., Kim, S.-B., Goodfellow, M. \& Park, Y.-H. (1997a). Inter- and intraspecific genetic analysis of the genus 
Saccharomonospora with $16 \mathrm{~S}$ to $23 \mathrm{~S}$ ribosomal DNA (rDNA) and $23 \mathrm{~S}$ to $5 \mathrm{~S}$ rDNA internally transcribed spacer sequences. Int J Syst Bacteriol 47, 661-669.

Yoon, J.-H., Lee, S. T., Kim, S.-B., Kim, W. Y., Goodfellow, M. \& Park, Y.-H. (1997b). Restriction fragment length polymorphism analysis of PCR-amplified $16 \mathrm{~S}$ ribosomal DNA for rapid identification of Saccharomonospora strains. Int J Syst Bacteriol 47, 111-114.

Yoon, J.-H., Kim, S.-B., Lee, S. T. \& Park, Y.-H. (1999). DNA-DNA relatedness between Saccharomonospora species: 'Saccharomonospora caesia' as a synonym of Saccharomonospora azurea. Int $J$ Syst Bacteriol 49, 671-673. 